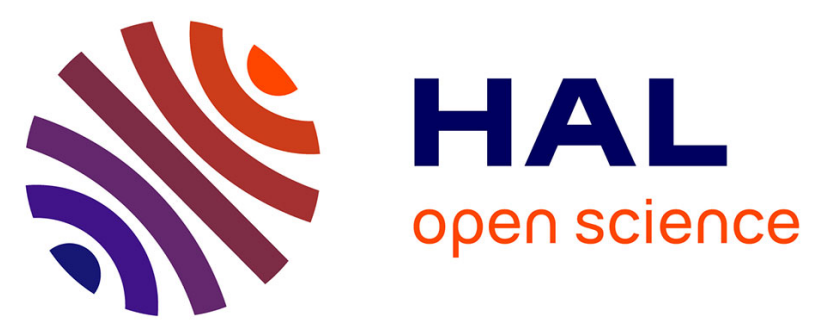

\title{
Mechanical twin sets in calcite as markers of recent collisional events in a fold-and-thrust belt: Evidence from the reefal limestones of southwestern Taiwan
}

\author{
M. Rocher, Olivier Lacombe, J. Angelier, H.-W. Chen
}

\section{- To cite this version:}

M. Rocher, Olivier Lacombe, J. Angelier, H.-W. Chen. Mechanical twin sets in calcite as markers of recent collisional events in a fold-and-thrust belt: Evidence from the reefal limestones of southwestern Taiwan. Tectonics, 1996, 15 (5), pp.984 - 996. 10.1029/96TC00625 . hal-01402201

\section{HAL Id: hal-01402201 \\ https://hal.sorbonne-universite.fr/hal-01402201}

Submitted on 24 Nov 2016

HAL is a multi-disciplinary open access archive for the deposit and dissemination of scientific research documents, whether they are published or not. The documents may come from teaching and research institutions in France or abroad, or from public or private research centers.
L'archive ouverte pluridisciplinaire HAL, est destinée au dépôt et à la diffusion de documents scientifiques de niveau recherche, publiés ou non, émanant des établissements d'enseignement et de recherche français ou étrangers, des laboratoires publics ou privés. 


\title{
Mechanical twin sets in calcite as markers of recent collisional events in a fold-and-thrust belt: Evidence from the reefal limestones of southwestern Taiwan
}

\author{
M. Rocher, O. Lacombe, and J. Angelier \\ Laboratoire de Tectonique Quantitative, Université Pierre et Marie Curie, Paris, France
}

H.-W. Chen

Central Geological Survey, Taipei, Taiwan

\begin{abstract}
Stress reconstructions were carried out based on inversion of calcite twin data from slightly deformed Quaternary refal limestones from SW Taiwan. Results demonstrate that twinning reliably recorded the complex Quaternary and present-day stress fields in a young mountain range undergoing collisional shortening. The stress regimes reconstructed at microscopic scale are predominantly compressional and reflect the main stages of the neotectonic evolution of the collision belt. No twinning has been observed in a sample collected in the Holocene platform of southern Taiwan, indicating that these formations did not undergo sufficient stress to initiate calcite twinning. Three different stress regimes have been recorded in the samples collected in Pleistocene reef limestones that developed in relation to active fold systems of the Western Foothills. These regimes appear to be homogeneous at the site scale and at the scale of SW Taiwan. The reconstructed ENE and NW trending compressions, only present in SW Taiwan, probably reflect local perturbations of the regional $105^{\circ}$ trending compression. The perturbation might be due to activation of a set of folded-faulted blocks in the studied area. A NW-SE extension, also identified in these samples, is related to extrados stretching due to fold development. The results are consistent with independent stress data, i.e., Quaternary faulting, borehole breakouts, and focal mechanisms of earthquakes. The analysis of mechanical twins in calcite rocks constitutes a powerful tool for tectonic analyses in fold-andthrust belts.
\end{abstract}

\section{Introduction}

Arc-continent collision is occurring in the Taiwan segment of the active convergent plate boundary between the Philippine Sea plate and Eurasia [Bowin et al., 1978; Suppe, 1981; Ho, 1986; Barrier and Angelier, 1986; Tsai, 1986]. This collision segment connects the south verging Ryukyu subduction zone, where the Philippine Sea plate is subducting beneath the Eurasian plate, and the west verging Manila

Copyright 1996 by the American Geophysical Union.

Paper number 96TC00625.

0278-7407/96/96TC-00625\$12.00 subduction zone, where the Philippine Sea plate is overriding the crust of the South China Sea (Figure 1a).

Since the late Quaternary, the azimuth of convergence between these two plates has been nearly $120^{\circ}\left(\mathrm{N} 120^{\circ} \mathrm{E}\right)$. On Taiwan the pattern of related late Cenozoic maximum compressional stress axes, $\sigma_{1}$, is fan-shaped: along the front of the belt, the compression turns clockwise from E-W to WNW-ESE in southern and central Taiwan to NW-SE in the north [Angelier et al., 1986].

The two main geological provinces of Taiwan are separated by the active Longitudinal Valley Fault (Figure 1b). To the east the Coastal Range comprises mainly volcanic and siliclastic rocks of the accreted Luzon arc-trench system, whereas the area to the west consists of metamorphic and sedimentary sequences of the deformed continental margin [Ho, 1986; Teng, 1987, 1990]. The Tananao metamorphic complex of the Central Range can be regarded as the continental basement of the Eurasian margin and the Tcrtiary sequences of the slate belt and the Western Foothills as the overlying sedimentary cover (Figure $1 b$ ). The coastal plain of western Taiwan and the offshore areas to the west are underlain by flat-lying Cenozoic sedimentary sequences which have not yet been deformed by the collision.

In active mountain belts like that of Taiwan, deciphering the Pliocene-Quaternary compressional events is a crucial step for understanding the late Cenozoic tectonic evolution of the collision zone. Outcrops of Pliocene-Pleistocene sedimentary deposits of the western foreland basin are scarce because they are often covered by Holocene alluvium deposits. However, recently uplifted reefal limestone of Pleistocene age locally exposed at the front of the belt in southern Taiwan (Figure 1b) provides a good opportunity to analyze recent deformation.

The goals of this paper are, first, to provide evidence that mechanical twins developed within these Pleistocene limestones in response to stresses associated with recent collisional events and, second, to demonstrate that these mechanical twins reliably indicate the orientations of stresses directly related to Quaternary-present-day mountain building in Taiwan.

\section{Geometry and Occurrence of Mechanical Twinning in Calcite}

Twin lamellae are a common microscopic feature in calcite [e.g., Handin and Griggs, 1951; Turner et al., 1954; Friedman, 


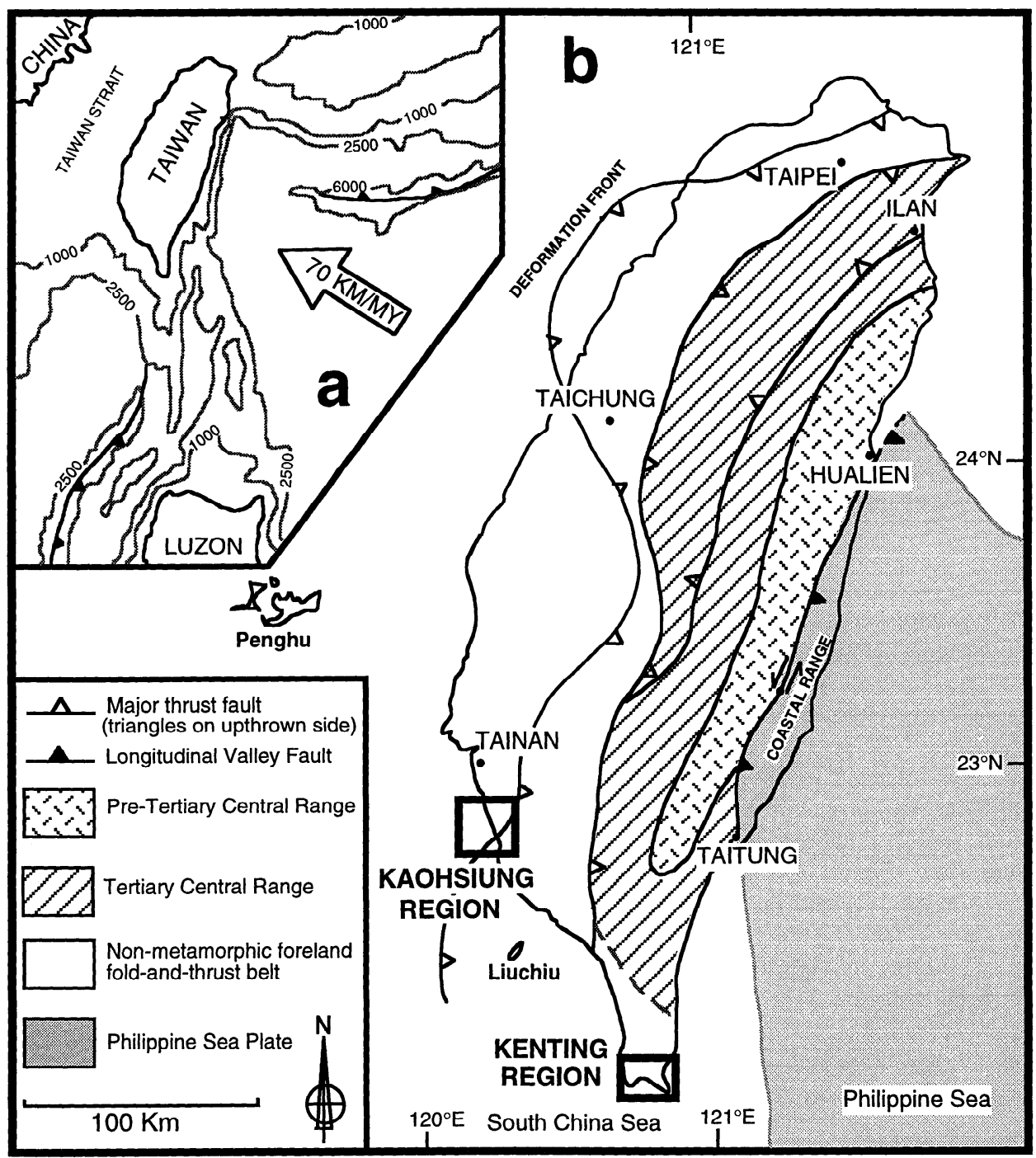

Figure 1. (a) Geotectonic setting of Taiwan. Isobaths are in meters; large open arrow shows the present direction of convergence of the Philippine Sea plate relative to Eurasia. (b) Main structural units of Taiwan (modified from Angelier et al. [1990]).

1964]. A twin lamella results from the simple shear of part of the host crystal in a particular sense and direction along crystallographically defined planes [Turner et al., 1954] in such a way that the resulting twinned portion of the crystal bears a mirrored crystallographic orientation to the untwinned portion across the twin plane (Figure 2). At low pressure and temperature, calcite aggregates deform primarily by twinning on $\{01 \overline{1} 2\}$ planes. In thin section, the resulting $e$-twin lamellae are straight and very thin (less than a micron). Each crystal contains three potential $e$-twin planes that are arranged symmetrically around the $c$ axis.

Twinning requires a resolved shear stress $\tau_{s}$ (the component of applied stress along the twinning direction) that exceeds a critical value, $\tau_{a}$. This critical value depends little on temperature and confining pressure [Friedman and Heard, 1974] but depends on grain size [Rowe and Rutter, 1990]. The value of $\tau_{a}$ can, however, be regarded as stable for samples displaying a nearly homogeneous grain size. Experiments have provided a $\tau_{a}$ value of $10 \mathrm{MPa}$ for a mean grain size of
200-400 mm [Turner et al., 1954; Tullis, 1980], although in natural deformation, the actual value of the yield stress may be lower [Tourneret and Laurent, 1990]. Consequently, calcite twinning analysis is suitable for reconstructing paleostresses in nonmetamorphic, very weakly deformed carbonate cover rocks.

\section{Sampling in the Pleistocene Reefal Limestones of Southern Taiwan}

The samples analysed have been collected from Quaternary calcareous reefs in the foreland of the recent and still active fold-and-thrust belt of Taiwan. The reef limestones are the only Quaternary and shallow-marine facies found on the island which contain some sparitic calcite. These formations were located on submarine structural highs raised by folding [e.g., Gong et al., 1995], or along the Quaternary shorelines. The onland exposure of these reefs was caused by the recent uplift of the chain due to the collision; the reefs were never significantly buried. 


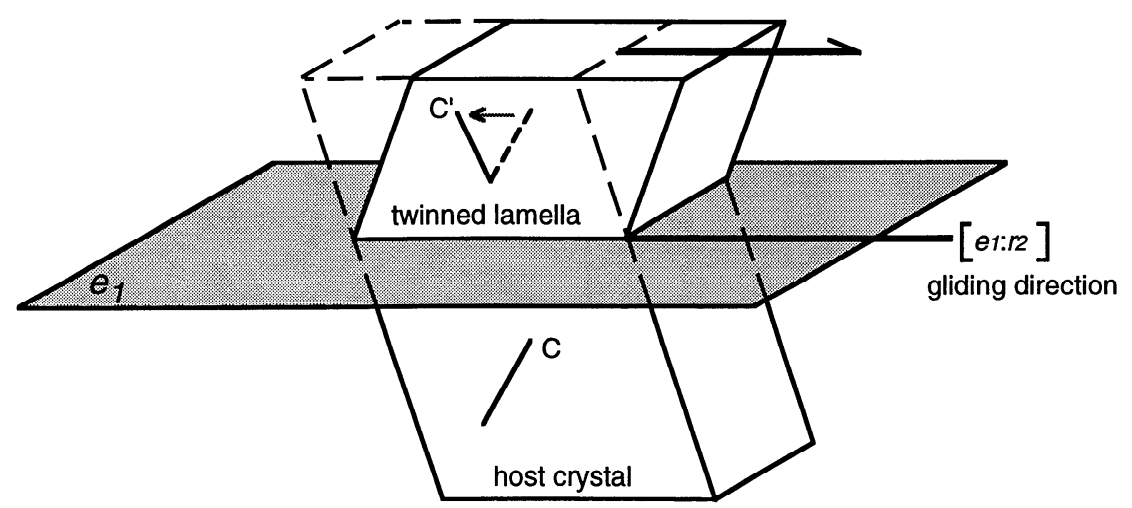

Figure 2. Schematic sketch of a twin lamella $\{01 \overline{1} 2\}$ in a calcite crystal. Here $C$ and $C^{\prime}$ are optical axes of host crystal and twin lamella, respectively. The arrow indicates twinning direction [e1:r2], corresponding to direction of motion of the crystal part located above the twin plane, and sense of shear as imposed by crystal geometry.

The sampled formations crop out as thick, subhorizontal, or gently dipping reef limestone belonging to the front zone of the mountain belt. These coarse crystalline limestones are generally found as large lenses interbedded within the detritic Guntingkeng formation [e.g., Chen et al., 1994] (Figure 3). Eleven samples have been collected in the eastern flanks of the folds, where reefal limestones display a shallow dip of $10^{\circ}$ $20^{\circ}$ to the ESE, from five Pleistocene formations in the Kaohsiung area (four sites, Figure 4a) and the Kenting peninsula (one site; Figure 4b), located in southwestern and southernmost Taiwan, respectively (Figure 1). Their structural positions and geological settings are shown in Figure 4. Two or three samples have been collected from each of these sites in order to provide a mutual control of the results. The relative stratigraphic positions of these five sites, with ages ranging from 1.2 to $0.2 \mathrm{Ma}$, are shown in Figure 3.

\section{The Holocene Pilot Sample}

An additional sample was collected for a control experiment in a superficial undeformed Holocenc recf formation, located near the present-day shoreline in the Kenting peninsula, south of Checheng (sample 12), $20 \mathrm{~m}$ above sea level (Figure 4b). This formation has never been buried or eroded. No mechanical twin was found in the thin sections of this sample although aggregates of large sparitic calcite crystals are present (Figure 5a). Stresses near the surface were probably never high enough to induce twinning; that is the critical resolved shear stress was never reached. In addition, the absence of twins in this sample shows that no twin developed during diagenesis (i.e., growth twins). Comparison of Holocene and Pleistocene reef limestones based on microscopic observations indicates that both types of rocks followed a similar history for diagenesis

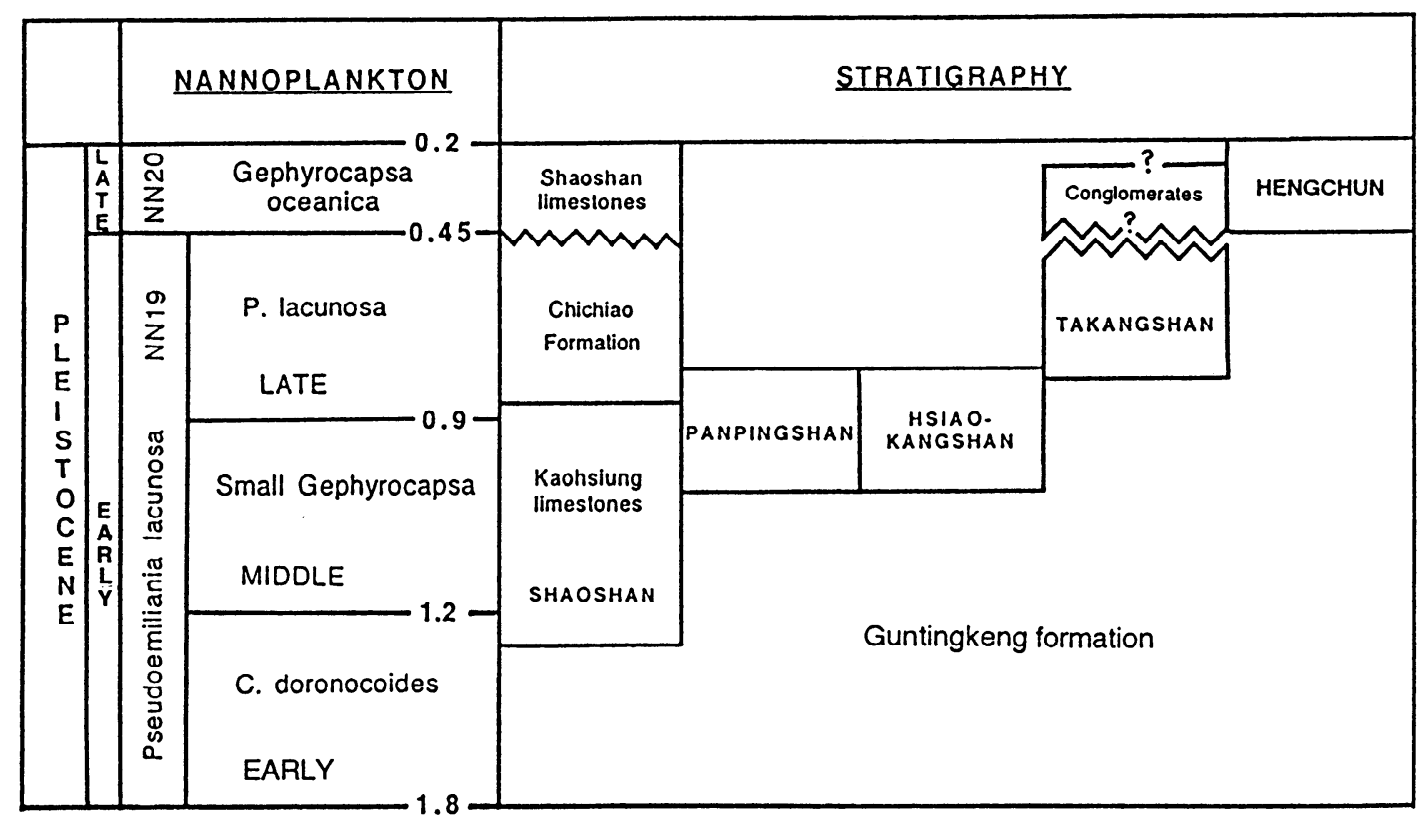

Figure 3. Age (Ma) and stratigraphic position of investigated reef limestones. Formations (NN19 and NN20 zones) were dated with nannoplankton [Chi, 1979; Chi et al., 1981]. 


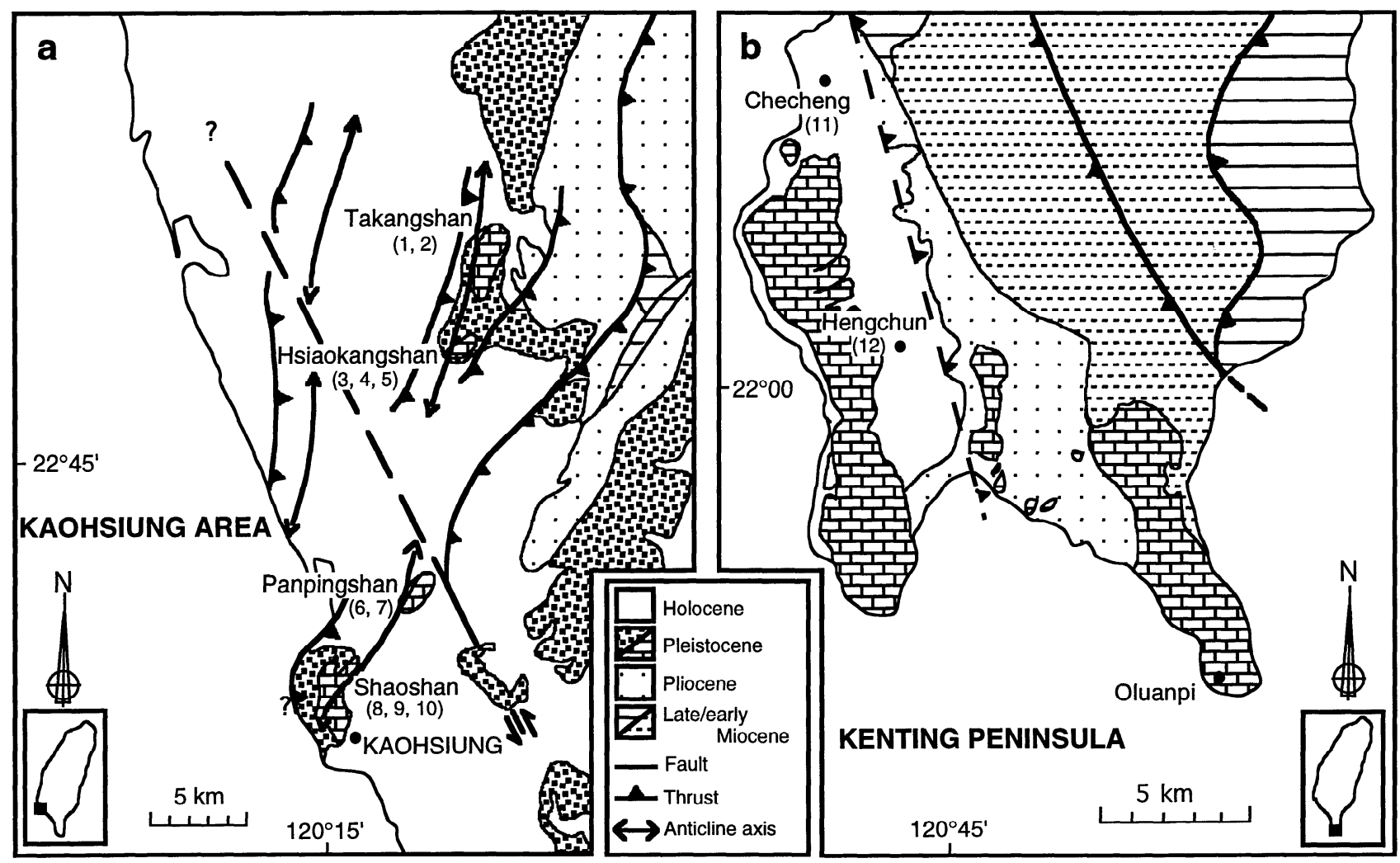

Figure 4. Location of sampling areas (adapted from Geological Map of Taiwan, Ho [1986], and Sun [1963]).

(a): Kaohsiung area. (b): Kenting region.

and recrystallization. Therefore we conclude that growth twins are rare in all the samples studied.

\section{Microscopic Structure of the Pleistocene Reefal Limestones}

The large sparitic calcite crystals observed in the Pleistocene reefal limestones resulted from recrystallization of the initial aragonitic material and the primary micritic calcite during diagenesis. These sparite grains developed independently with respect to the initial organic network (cells, beams of crystals, fibrous skeletons), and thus display a nearly random crystallographic orientation (Figures $5 \mathrm{~b}$ and 6).

Measurements in the Pleistocene samples were made on the sparitic calcite crystals which display nearly constant grain size in each sample. The straight and narrow twin lamellae indicate that these samples have undergone low strain (typically less than 2 or $3 \%)$ at low temperature $\left(<300^{\circ} \mathrm{C}\right)$ [e.g., Groshong, 1974; Friedman et al., 1976; Groshong et al., 1984; Laurent, 1984] .

In the Kaohsiung region, the Takangshan samples show a lot of twin lamellae in each crystal (high "twin density"), and some twins have been bent by secondary gliding on the $r$ $\{10 \overline{1} 1\}$ planes. The deformation was certainly larger than in the other sites studied, maybe due to a nearby strike-slip fault. However, the size and the transparency of the grains (Figures $5 \mathrm{~b}$ and $5 \mathrm{c}$ ) made measurements of (win orientation easy. The samples of the Hsiaokangshan area show very few heterogeneities, but measurements in the samples 3 and 4 were difficult, because of the small size of the grains and the extreme thinness of twin lamellae. The Panpingshan samples have numerous heterogeneitics (fluid inclusions, organic matter, other inlayed crystals), but grain size is uniform. The Shaoshan samples show many heterogeneities and very thin twin lamellae (Figure 5d). The Hengchun sample includes various primary depositional features, with micritic and sparitic crystals with variable size and bended shapes which apparently follow the configuration of coralline structures. Because of the important residues of organic matter and the thinness of the twin lamellae, the quantity of reliable measurements is significantly lower than for the other samples.

No particular crystallographic preferred orientation was detected in most samples: optical axis orientations of crystals are generally random (Figure 6, sample 6). Samples 7 (Figure 6 ) and 10, however, show a weak preferred orientation of the optical axes.

\section{Calcite Twin Data Inversion and Paleostress Determination}

Because the very small strain involved by twinning in our samples can be approximated by coaxial conditions, this strain can be directly correlated with (paleo)stress. In this paper, we chose to focus on stress (rather than strain) tensor calculation for several reasons. From a practical point of view, measurements for stress tensor determination are easier and 
(a)

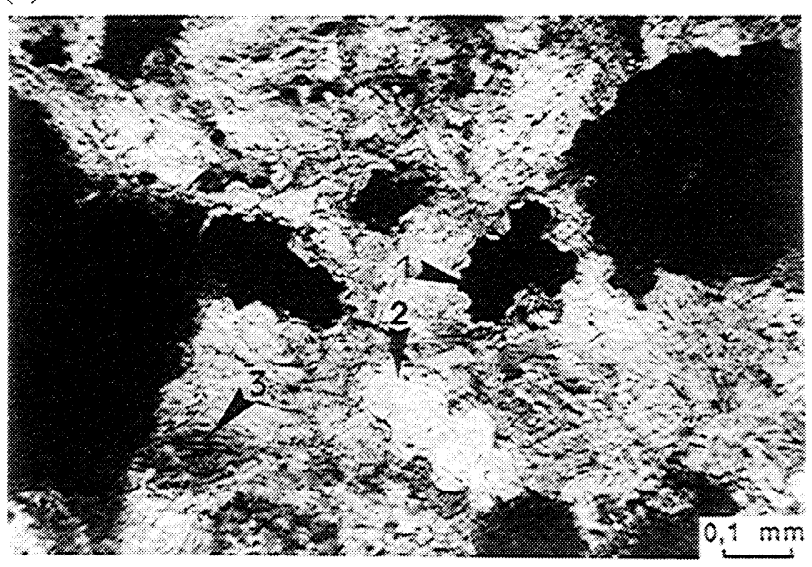

(b)

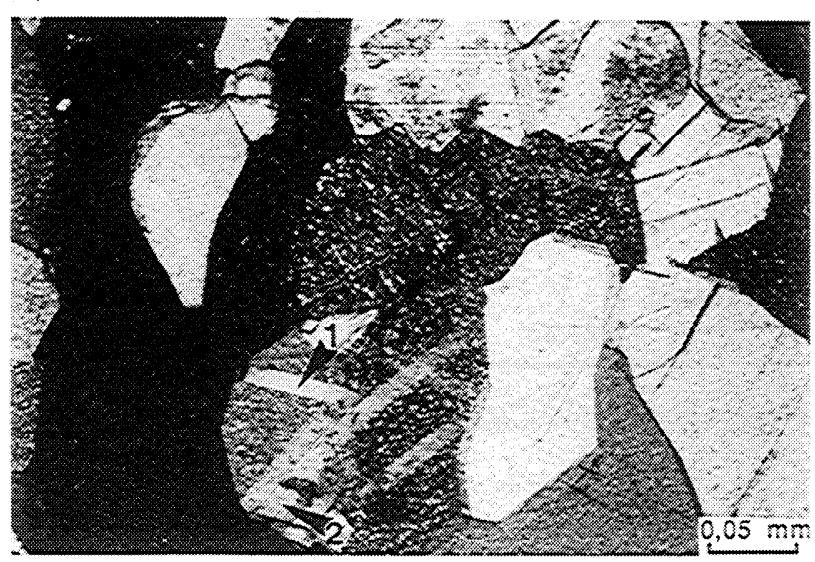

(c)

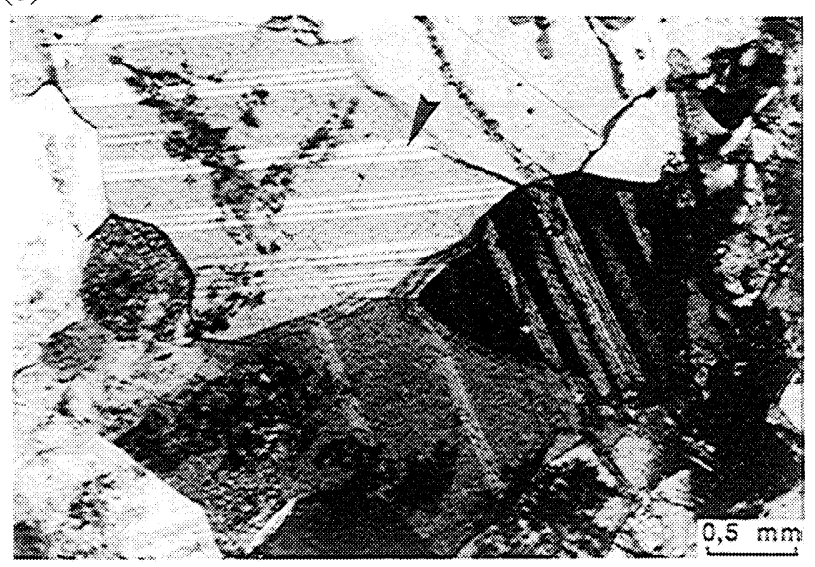

(d)

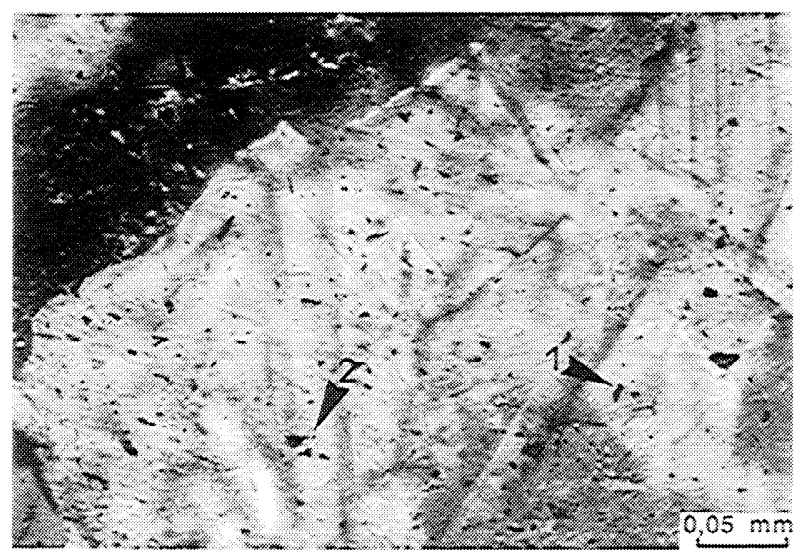

Figure 5. Photomicrographs (natural light) of Holocene and Pleistocene samples. (a) Holocene sample of Checheng; spicules of Alcyonaria with micritic calcite and organic matter (black; arrow 1) or recrystallized into sparitic calcite (white; arrow 2); calcite crystals with structure in beams (arrow 3); no twin is observed. (b) Pleistocene sample of Takangshan; crystals with few heterogeneities, displaying nearly homogeneous grain size and random orientation. Crystal with two families of twinned $e$ planes ( $\mathrm{e}_{1}$, arrow $1 ; \mathrm{e}_{2}$, arrow 2). (c) Pleistocene sample of Takangshan. Crystals with only one clearly visible twin set ( $e_{1}$, arrow). (d) Pleistocene sample of Shaoshan; very thin twins in impure crystals (organic matter, arrow 1, and solid inclusions, arrow 2).

less time consuming than those needed for strain tensor determination [e.g., Groshong, 1974], because they do not need measuring of the number and the volume of twin lamellae but only their orientation [Burkhard, 1993]. In addition, twinning strain may be very heterogeneous at the grain scale (because of fluid or solid inclusions, pores, variation in grain size) and may not reflect the bulk strain imposed to the rock, whereas stress is generally more homogeneous at the grain scale [e.g., Spiers, 1979]. Finally, this work aims at correlating results obtained at microscopic scale with the analysis of other independent stress indicators, that is, fault slip data, borehole breakouts, and earthquake focal mechanisms.

Since the pioneering work of Turner [1953], it is known that analyzing twinning in calcite grains may lead to the orientation of the principal stresses responsible for twinning, and numerous methods have subsequently been proposed [Nissen, 1964; Dietrich and Song, 1984; Laurent et al., 1981,
1990; Etchecopar, 1984; Pfiffner and Burkhard, 1987]. In this paper, determination of paleostress orientations from calcite twin data is performed by computerized inversion [Etchecopar, 1984], which takes into account both the potential twin planes oriented so that the resolved shear stress $\tau_{s}$ was greater than $\tau_{a}$ (i.e., twinned planes) and the potential twin planes oriented so that $\tau_{s}$ was lower than $\tau_{a}$ (i.e., untwinned planes).

Assuming nearly homogeneous state of stress at the grain scale and constant critical resolved shear stress for twinning, the inverse problem consists of finding the stress tensor that best fits the distribution of measured twinned and untwinned planes. In the reference to the principal stress axes, the stress tensor $T$ is

$$
T=\left[\begin{array}{ccc}
\sigma_{1} & 0 & 0 \\
0 & \sigma_{2} & 0 \\
0 & 0 & \sigma_{3}
\end{array}\right]
$$



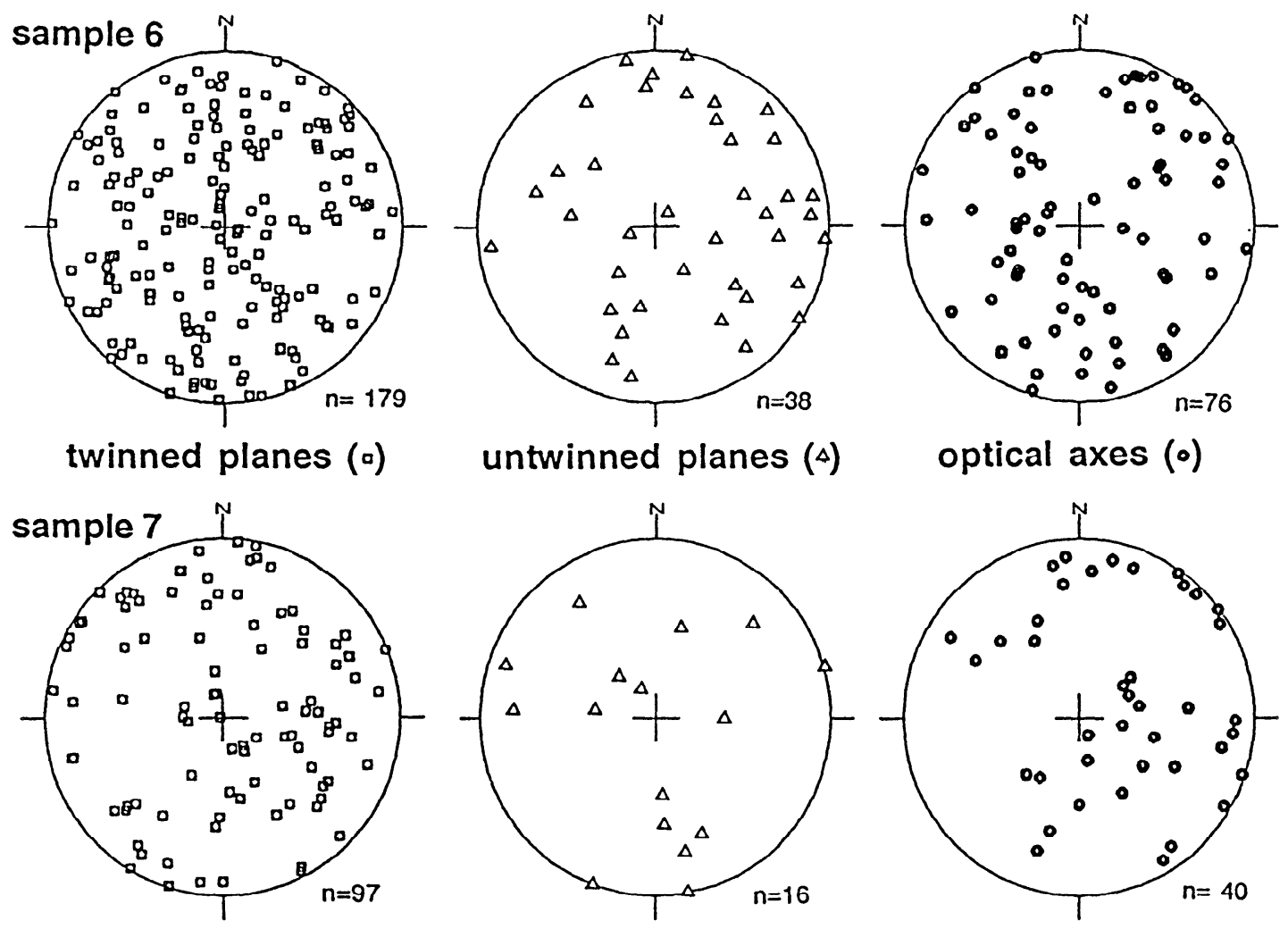

Figure 6. Distribution of poles to twinned planes, poles to untwinned planes, and optical axes for samples 6 and 7 from Panpingshan (lower hemisphere, equal area projection).

with $\sigma_{1} \geq \sigma_{2} \geq \sigma_{3}$, pressure noted positive. We can reduce $T$ into $T^{\prime}$ by subtracting $\sigma_{3}$ from $T$,

$$
T^{\prime}=\left[\begin{array}{ccc}
\left(\sigma_{1}-\sigma_{3}\right) & 0 & 0 \\
0 & \Phi *\left(\sigma_{1}-\sigma_{3}\right) & 0 \\
0 & 0 & 0
\end{array}\right]
$$

with $\Phi=\left(\sigma_{2}-\sigma_{3}\right) /\left(\sigma_{1}-\sigma_{3}\right)$, so that $0 \leq \Phi \leq 1$. The reduced tensor $T^{\prime}$ depends on five parameters: the oricntations of principal stress axes, the $\Phi$ ratio, and the differential stress $\left(\sigma_{1}-\sigma_{3}\right)$. The tensor solution is searched as a reduced stress tensor such as $\left(\sigma_{1}-\sigma_{3}\right)$ is scaled to $1\left[\left(\sigma_{1}-\sigma_{3}\right)^{*}=1\right]$. As a result of this scaling, the resolved shear stress, $\tau_{s}$, acting along any twin plane comprises between -0.5 and 0.5 , that is, $-\left(\sigma_{1}-\sigma_{3}\right) / 2$ and $\left(\sigma_{1}-\sigma_{3}\right) / 2$ [Jamison and Spang, 1976; Laurent, 1984].

The tensor solution must theoretically meet the major requirement that all the twinned planes consistent with it should sustain a resolved shear stress $\tau_{s}$ larger than that exerted on all the untwinned planes. The first step of the inversion consists of obtaining an initial guess of the solution by applying a number of random tensors. For each tensor, the stress components are calculated for all the twinned and the untwinned planes. However, because the resolved shear stress $\tau_{s}$ exerted on some untwinned planes may in practice be greater than that exerted along some twinned planes compatible with the tensor, the second step of the process consists of minimizing the function $f$, ideally equal to 0 , defined as

$$
f=\sum_{\mathbf{j}=\mathbf{1}}^{\mathbf{N}}\left(\tau_{\mathbf{s} \mathbf{j}}-\tau_{\mathbf{a}^{\prime}}\right),
$$

where $\tau_{a}^{\prime}$ is the smallest resolved shear stress applied on the twinned planes consistent with the tensor and $\tau_{s j}$ are the resolved shear stresses applied on the $N$ untwinned planes $j$ such that $\tau_{s j}>\tau_{a}^{\prime}$ (for details, refer to Etchecopar [1984] and discussion by Tourneret and Laurent [1990] and Lacombe [1992]).The value of $\tau_{a}{ }^{\prime}$ may be considered as the yield stress value for the reduced stress tensor (i.e., with $\left(\sigma_{1}-\sigma_{3}\right) *=1$ ). This optimization process leads to the stress tensor solution that includes the largest number of twinned planes and simultaneously corresponds to the smallest value of $f$. The orientations of the three principal stresses $\sigma_{1}, \sigma_{2}$ and $\sigma_{3}$, and the $\Phi$ ratio, which indicates the magnitude of $\sigma_{2}$ relative to $\sigma_{1}$ and $\sigma_{3}$, are calculated. The fifth parameter $\left(\sigma_{1}-\sigma_{3}\right)$ of the reduced tensor $T^{\prime}$ can be determined based on $\tau_{a}$ and $\tau_{a}$ values. Because it is not the aim of this paper to focus on the calculation of differential stress magnitudes, this point will not be addressed further.

Figure 7 shows an example of a normal stress $\left(\sigma_{N}\right) /$ resolved shear stress $\left(\tau_{S}\right)$ diagram for the stress tensor determined during an initial calculation in sample 7 from Panpingshan. The best tensor corresponds to the $\tau_{a}{ }^{\prime}$ value such that this tensor accounts for a maximum of twinned planes and a maximum of untwinned planes. The $\tau_{a}{ }^{\prime}$ value equals 0.079 .

When many twins are found inconsistent with a single stress tensor (in sample 7, 55\% of the twins are inconsistent with the first tensor solution), the twinned planes consistent 


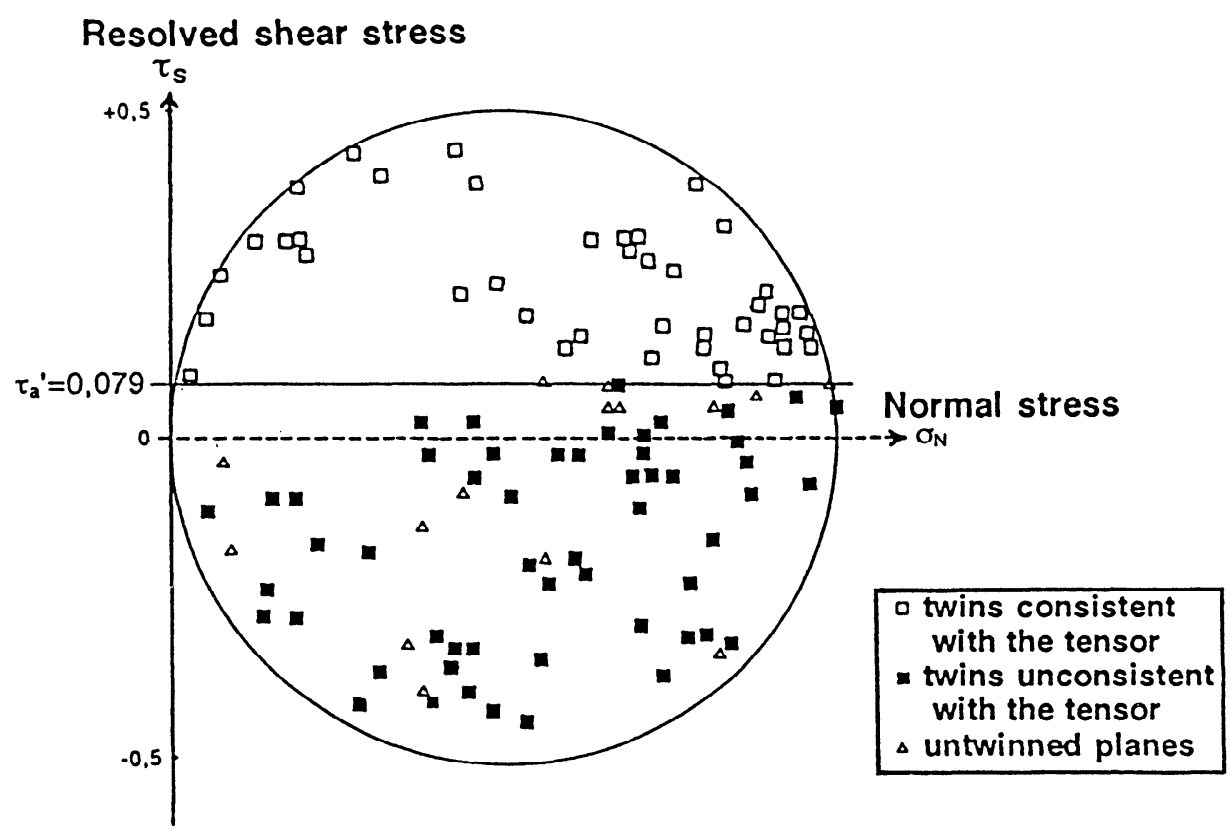

Figure 7. Resolved shear stress $\tau_{\mathrm{s}}$ /normal stress $\sigma_{\mathrm{N}}$ diagram, corresponding to the first stress tensor ( $\sigma_{1}$, $\left.150-26 ; \sigma_{2}, 069-01 ; \sigma_{3}, 049-50\right)$ determined by inversion of twin data from sample 7 (Panpingshan). See text for details.

with this tensor are withdrawn, and the process is repeated with the residual twinned planes and the whole set of untwinned planes (the untwinned planes should remain untwinned for any reconstructed tensors). Where polyphase tectonism has occurred, this process allows separation of superimposed stress tensors, each of them accounting for part of the data. Such separation, usually supported by independent geological evidence (e.g., heterogeneous populations of fault slip data, Lacombe et al. [1990, 1992]), was systematically applied to our samples [Rocher, 1994, 1996]. Uncorrelated residues should be discarded as being noise. In all cases, the final analysis of the misfits provides indirect control of the validity of the assumptions made.

\section{Local Results of the Pleistocene Paleostress Determination Using Calcite Twin Data}

About $\sim 20-30$ crystals were analyzed in each of three mutually perpendicular thin sections for each oriented sample. In each crystal examined, the spatial orientations of the $c$ axis and of the three $e$-twin planes were determined by using a polarizing microscope combined with a three-axis universal stage. The twinned or untwinned character of each $e$-twin plane was optically checked. We thus obtained about $\sim 200$ twin data in each sample. Ambiguous data (for which the twinned or untwinned character could not be optically checked with certainty) were removed. Consequently, the number of data collected in a sample is generally less than three times the total number of measured crystals.

As an example, the application of the inverse method to the samples 6 and 7 of Panpingshan is demonstrated. The distributions of optical axes and poles of twinned and untwinned planes are shown (Figure 6). In sample 6, three tensors have been successively determined from 179 twinned planes and 38 untwinned planes. The first tensor obtained is consistent with $54 \%$ of the twinned planes measured (98 twinned planes); it corresponds to a compression with an horizontal $\sigma_{1}$ trending $133^{\circ}$ and a vertical $\sigma_{2}$ axis (Table 1 , 1 st line of sample 6). The analysis is repeated for the whole set of untwinned planes and the remaining subset of twins. The second tensor thus obtained corresponds to extension trending $131^{\circ}$; the $\sigma_{1}$ axis is nearly vertical. This second tensor accounts for $34 \%$ of the remaining twins (28 twins among the 82 remaining twinned planes; sce Table 1, 2nd linc of sample 6 ), representing $16 \%$ of the total number of twins. The third tensor obtained corresponds to a compression with $\sigma_{1}$ trending $067^{\circ}$ and $\sigma_{3}$ vertical; it was obtained by considering all untwinned planes and $69 \%$ of the twins remaining after determination of the two previous tensors (that is, 37 twins among 54 , or $21 \%$ on the total number of twinned planes measured; 3rd line of sample 6 in Table 1).

After these analyses, only $9 \%$ of data (17 twins) could not be accounted for by any significant stress tensor. They can be interpreted as due to dispersion, measurement errors and uncertainities, and local inhomogeneities (such as microindentation by harder crystals); they were rejected as being noise.

In the same locality of Panpingshan, sample 7 was also analyzed. Three tensors were determined (see the three lines of sample 7 in Table 1): (1) a compression with $\sigma_{1}$ oriented $150^{\circ}$ and $\sigma_{2}$ vertical (Figure 7); (2) a compression with $\sigma_{1}$ trending $069^{\circ}$ and $\sigma_{3}$ vertical, and (3) an extension with $\sigma_{3}$ trending $143^{\circ}$ and $\sigma_{1}$ vertical. A comparison between samples 6 and 7 reveals good compatibility of the results at the scale of the site, not only in terms of stress orientations but also in terms of $\Phi$ ratios (see Table 1). Such a high level of consistency between results for samples 6 and 7 indicates that the multiple 
Table 1. Results of Twin Data Analysis for the Kaohsiung and Kenting Samples

\begin{tabular}{|c|c|c|c|c|c|c|c|c|c|c|c|c|}
\hline \multirow[t]{2}{*}{$\begin{array}{l}\text { Sample } \\
\text { Number }\end{array}$} & \multirow{2}{*}{$\begin{array}{l}\text { Type of the } \\
\text { State } \\
\text { of Stress }\end{array}$} & \multicolumn{4}{|c|}{$\begin{array}{l}\text { Trend-Plunge of the Principal } \\
\text { Stress Axes, degrees }\end{array}$} & \multirow{2}{*}{$\begin{array}{l}\text { Ratio } \\
\text { Between } \\
\text { Differential } \\
\text { Stresses, } \Phi\end{array}$} & \multirow{2}{*}{$\begin{array}{l}\text { Function of } \\
\text { Minimiza- } \\
\text {-tion, } f\end{array}$} & \multirow{2}{*}{$\begin{array}{l}\text { Total } \\
\text { Number } \\
\text { of Twinned } \\
\text { Planes }\end{array}$} & \multirow{2}{*}{$\begin{array}{l}\text { Total } \\
\text { Number of } \\
\text { Untwinned } \\
\text { Plancs }\end{array}$} & \multirow{2}{*}{$\begin{array}{l}\text { Twinned } \\
\text { Planes } \\
\text { Explained }\end{array}$} & \multirow{2}{*}{$\begin{array}{l}\text { Untwinned } \\
\text { Planes } \\
\text { Inconsistent } \\
\text { with Tensor }\end{array}$} & \multirow{2}{*}{$\begin{array}{l}\text { Quality } \\
\text { of the } \\
\text { Tensor }\end{array}$} \\
\hline & & \multicolumn{2}{|l|}{$\sigma_{1}$} & $\sigma_{2}$ & $\sigma_{3}$ & & & & & & & \\
\hline & & & & & & & Kangshan Site & & & & & \\
\hline \multirow[t]{3}{*}{1} & NW-SE comp & 3402 & 23 & 21155 & 8124 & 0.7 & 0.25 & 173 & 26 & 79 & 5 & B \\
\hline & NW-SE ext & 1288 & 83 & 2453 & 3356 & 0.7 & 0.27 & 95 & 26 & 48 & 5 & B \\
\hline & E-W comp & 100 & 9 & 19321 & 34867 & 0.3 & 0.32 & 53 & 20 & 40 & 5 & B \\
\hline \multirow[t]{4}{*}{2} & NW-SE comp & 1211 & 17 & 24864 & 2520 & 0.2 & 0.14 & 206 & 22 & 92 & 3 & A \\
\hline & extension? & 152 & 22 & 14357 & 27524 & 0.7 & 0.41 & 114 & 22 & 62 & 4 & B \\
\hline & NW-SE ext & 2895 & 51 & 4721 & 15031 & 0.5 & 0.03 & 53 & 22 & 29 & 2 & B \\
\hline & \multicolumn{12}{|c|}{ Hsiaokangshan Site } \\
\hline \multirow[t]{2}{*}{3} & NW-SE comp & 2942 & 22 & 13766 & $27 \quad 8$ & 0.5 & 0.50 & 176 & 20 & 98 & 5 & A \\
\hline & NW-SE ext & 218 & 2 & 12171 & $309 \quad 19$ & 0.6 & 0.20 & 79 & 19 & 35 & 2 & $\mathrm{~B}$ \\
\hline \multirow[t]{3}{*}{4} & E-W comp & 791 & 17 & 26273 & $\begin{array}{ll}169 & 1\end{array}$ & 0.2 & 0.03 & 127 & 25 & 60 & 2 & A \\
\hline & NW-SE comp & 316 & 2 & 5473 & 22617 & 0.6 & 0.21 & 71 & 24 & 30 & 2 & A \\
\hline & NW-SE ext & 2717 & 70 & 238 & 11519 & 0.6 & 0.37 & 41 & 24 & 20 & 4 & B \\
\hline \multirow[t]{4}{*}{5} & NW-SE comp & 289 & 2 & 19819 & 2571 & 0.2 & 0.18 & 173 & 63 & 57 & 1 & A \\
\hline & E-W comp & 793 & 33 & 24556 & $344 \quad 6$ & 0.5 & 0.40 & 116 & 63 & 34 & 5 & $\mathrm{C}$ \\
\hline & NW-SE ext & 17 & 7 & 20382 & $108 \quad 1$ & 0.5 & 0.8 & 89 & 57 & 34 & 5 & $\mathrm{C}$ \\
\hline & \multicolumn{12}{|c|}{ Panpingshan Site } \\
\hline \multirow[t]{3}{*}{6} & NW-SE comp & 133 & 2 & 35088 & $223 \quad 1$ & 0.5 & 1.02 & 179 & 38 & 98 & 7 & $\mathrm{~B}$ \\
\hline & NW-SE ext & 3467 & 73 & 2249 & 13114 & 0.6 & 0.27 & 82 & 36 & 28 & 5 & $\mathrm{C}$ \\
\hline & E-W comp & 672 & 22 & 16722 & 29757 & 0.5 & 0.79 & 54 & 36 & 37 & 8 & $\mathrm{C}$ \\
\hline \multirow[t]{4}{*}{7} & NW-SE comp & 1502 & 26 & 30762 & $56 \quad 10$ & 0.6 & 0.00 & 97 & 16 & 43 & 0 & B \\
\hline & E-W comp & 69 & 1 & 33919 & 16371 & 0.4 & 0.00 & 55 & 15 & 26 & 0 & A \\
\hline & NW-SE ext & 435 & 50 & 23939 & 1438 & 0.1 & 0.10 & 29 & 15 & 17 & 3 & $\mathrm{C}$ \\
\hline & \multicolumn{12}{|c|}{ Shaoshan Site } \\
\hline \multirow[t]{3}{*}{8} & NW-SE comp & 127 & 9 & 3321 & 23967 & 0.3 & 0.36 & 175 & 19 & 94 & 3 & A \\
\hline & $?$ & 2256 & 63 & 1264 & 3427 & 0.3 & 0.14 & 81 & 19 & 36 & 2 & A \\
\hline & NW-SE ext & 272 & 25 & 27043 & 13736 & 0.2 & 0.20 & 45 & 19 & 29 & 4 & $\mathrm{C}$ \\
\hline 9 & NW-SE comp & 1342 & 26 & 34461 & 23013 & 0.4 & 0.08 & 84 & 20 & 37 & 2 & $\mathrm{~A}$ \\
\hline & $\mathrm{E}-\mathrm{W}$ comp & 243 & 4 & 14855 & 33535 & 0.2 & 0.06 & 47 & 20 & 18 & 2 & B \\
\hline 10 & NW-SE ext & 232 & 8 & 35675 & $141 \quad 12$ & 0.9 & 0.09 & 151 & 66 & 46 & 2 & B \\
\hline & E-W comp & 242 & 4 & 33313 & 13576 & 0.6 & 0.15 & 109 & 62 & 35 & 3 & B \\
\hline & & & & & & & ngchun Site & & & & & \\
\hline 11 & NW-SE ext & 2101 & 15 & 6872 & 30311 & 0.4 & 0.26 & 77 & 15 & 42 & 2 & $\mathrm{~A}$ \\
\hline & E-W comp & 93 & 1 & 30389 & 1830 & 0.5 & 0.00 & 36 & 14 & 18 & 0 & $\mathrm{~B}$ \\
\hline & NW-SE comp & 304 & 6 & 16681 & 346 & 0.2 & 0.17 & 35 & 15 & 25 & 2 & B \\
\hline
\end{tabular}

sources of inhomogeneity within the investigated rock material (fluid inclusions, organic matter, other inlayed crystals) have little effect on the internal consistency of the twin systems and hence on the results of inverse analysis. We conclude that twin analysis allows reliable determination of three states of stress in the Pleistocene rocks at Panpingshan: a NW-SE compression, a NW-SE extension, and an ENE-WSW compression. One may observe that for both samples the tensor calculated first (which corresponds to the largest number of twins, hence to the most important event) indicates the same NW-SE compression. In more detail, the stress orientations attributed to homogeneous events are correlatable within a range of $10^{\circ}$, consistent with the errors due to thinsection making, measurements, and orientation of the samples in the field.

For the remaining samples, the inversion procedure and the comparison of the results at the site scale will not be described: all the results are summarized in Table 1 . Standard deviation averages $\pm 10^{\circ}$ for orientations of $\sigma_{1}, \sigma_{2}$, and $\sigma_{3}$ (trends and plunges) and \pm 0.1 for $\Phi$ ratio (evaluation of uncertainties is discussed by Rocher [1996]). A semiquantitative quality estimate for each result, mentioned in 
Table 1 (A, good; B, medium; C, poor), was determined based on (1) the order of determination of the tensor in the process (first, second of third obtained), (2) the numerical stability of the solution, i.e., its sensitivity to addition or deletion of few twin data, (3) the percentage of twinned planes explained by the tensor solution, and (4) the percentage of untwinned planes inconsistent with the tensor.

Additional numerical analyses carried out with a single data set (not discussed herein [see Rocher, 1994, 1996]) show that the successive removal of the twins consistent with the previous tensors and the order of determination of tensors do not significantly modify the oricntations of the calculated stresses. However, in detail, a permutation of two stress axes may occur, as a probable result of the large sensitivity of $\Phi$ value determinations, and accordingly the number of twinned planes incorporated in the solution may slightly vary.

\section{Regional Correlations}

In order to provide a microstructural control of the calculated stress orientations and of their regional tectonic significance, the results of twin analyses will be first compared with each other (this section) and then (next scction) to the results independently obtained by fault slip data analysis collected in the same sites (Lacombe et al. [1993]; Lacombe et al., Syndepositional tectonics and extension-compression relationships at a fold and thrust belt front: a case study in the Pleistocene reefal limestones near Kaohsiung, Taiwan, submitted to Tectonophysics, 1996, hereinafter referred to as Lacombe et al., manuscript submitted, 1996). In addition, the results will be compared with the present-day state of stress deduced from borehole breakouts or earthquake focal mechanisms.
As discussed above for the Panpingshan samples, two or three tensors have been determined in each sample. Our results from different samples and sites consistently reveal three different states of stress: a NW-SE compression with $\sigma_{2}$ vertical, an ENE-WSW compression with $\sigma_{3}$ vertical, and a NW-SE extension (details in Table 1 and Figure 8).

The best result concerns the NW-SE compression (average $131^{\circ}$ trend; Figure 8), which was identified in all sites and samples. Furthermore, this compression was in most cases obtained in the first steps of the numerical calculation (Table 1). Concerning extension (average $133^{\circ}$ trend; Figure 8 ), the reconstructed trends are less homogeneous, and the quality of determinations is poorer (Table 1). The existence of an extensional stress which affected all the sites, however, is beyond doubt. In some sites, the NW-SE extension seems to be associated with a weak NE-SW shortening. We thus consider that the tensors with a NW-SE trending $\sigma_{3}$ axis should be related to the extensive NW-SE regime, even where $\sigma_{2}$ is vertical. Finally, an ENE trending compression (average $077^{\circ}$ trend; Figure 8) has been detected in all sites and in eight out of eleven samples. This state of stress is characterized by a vertical $\sigma_{3}$ axis in five cases, and a vertical $\sigma_{2}$ axis in the three other results.

\section{Consistency Between Calcite Twinning and Faulting}

In the sampling sites as well as in nearby stations, numerous tectonic features including striated faults and tension gashes were also measured [e.g., Lacombe et al., 1993]. We used these data as independent constraint on paleostress orientations. Faults were measured at Takangshan,

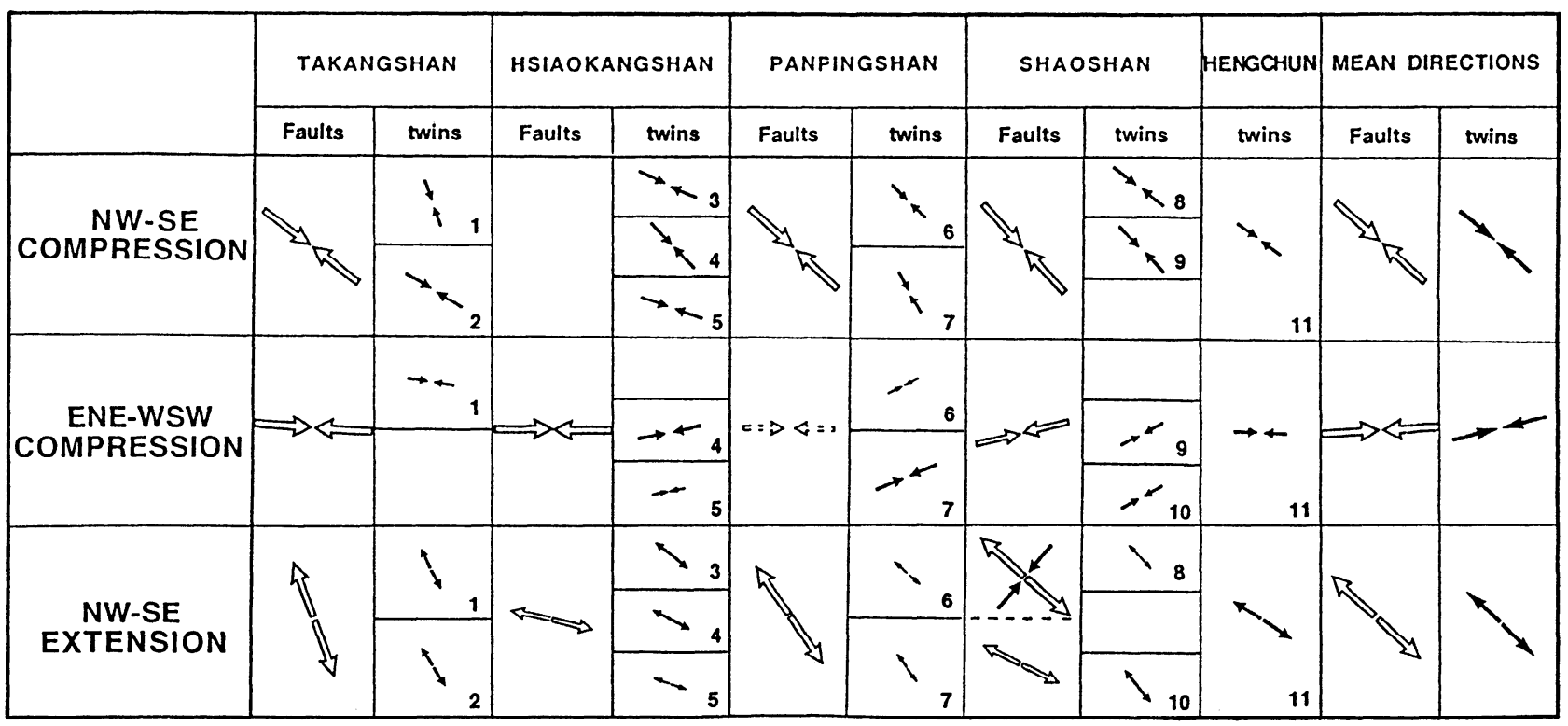

Figure 8. Summary of compressional ( $\sigma_{1}$, convergent arrows) and extensional trends ( $\sigma_{3}$, divergent arrows) resulting from twin analysis (solid arrows) and fault analysis (open arrows; Lacombe et al., submitted manuscript, 1996). The size of the arrows is proportional to the quality of the results (increasing from "C" to "A", see text). The first rows are the average directions of NW-SE and ENE-WSW compressions and NW-SE extension, obtained from twin and fault analyses. Numbers associatcd with twin rcsults indicate sample reference number 
Hsiaokangshan, Panpingshan, and Shaoshan. No fault was observed at Hengchun.

In each site of the Kaohsiung region, two or three tensors were determined (Figure 8) (Lacombe et al., submitted manuscript, 1996) based on the inversion of fault slip data [Angelier, 1984]. A NW-SE compression (average $128^{\circ}$ trend), a NW-SE extension (average $127^{\circ}$ trend), and an ENE-WSW compression (average $086^{\circ}$ trend) were identified. The extension corresponds to normal faults principally, but strikeslip faults are also present. Both the compressions correspond to strike-slip faults principally, but reverse faults are also present.

We conclude that the paleostress orientations calculated from minor fault patterns are remarkably consistent with those determined through the inversion of calcite twin data (Figure 8 ): both methods revealed a NW-SE compression (131 ${ }^{\circ}$ from twins and $128^{\circ}$ from faults), a NW-SE extension $\left(133^{\circ}\right.$ and $\left.127^{\circ}\right)$, and a nearly ENE-WSW compression $\left(077^{\circ}\right.$ and $\left.086^{\circ}\right)$. Moreover, most twins developed in reponse to stress regimes with subvertical $\sigma_{2}$ or $\sigma_{3}$ axes, which suggest that these stress regimes are predominantly compressional, in agreement with field observations of strike-slip faults associated with reverse faults and fold-and-thrust systems. The comparison between the analysis of fault slip data and our microscopic analysis of calcite twin data thus indicates that there is a good local as well as regional consistency between these independent paleostress reconstructions.

Calcite twin analysis should be considered as a more sensitive method in that some states of stress thus detected were not revealed by faults in each site, due to higher differential stress requirement for faulting to occur. Accordingly, no fault has been observed in the Pleistocene site of the Kenting peninsula, although three states of stress were clearly recognized by twin data inversion. The method should thus allow reconstitution of paleostresses in sites where no macroscopic tectonic feature is observable.

\section{Heterogeneity and Chronology of Pleistocene Stress Regimes}

The discovery of three states of stress in the Pleistocene formations was surprising because monophase tectonism was expected. This reveals that complex deformation occurred during a short time span.

When comparing the results of this study to the homogeneous ESE-WNW (105 ${ }^{\circ}$ ) direction of compression determined from Pleistocene formations in other sites of southern and central Taiwan based on fault analyses [Angelier et al., 1986], the Kaohsiung region clearly displays a heterogeneous, disturbed stress field. The presence of three different states of stress in the sites studied needs to be explained in the geological setting of southwestern Taiwan.

The heterogeneous stress distribution during the Quaternary cannot be consistently explained in terms of successive tectonic events. Rather, it is explained by local perturbation and reorientation of the $105^{\circ}$ trending regional compression. The Kaohsiung area displays major NE trending folds and reverse faults that affect the Pleistocene rocks (Figure 4) [Sun, 1963], connected by a major $\mathrm{N} 140^{\circ}$ transfer fault zone [Deffontaines et al., 1994]. Axes of folds trends are $017^{\circ}$, $015^{\circ}, 025^{\circ}$, and $040^{\circ}$ for the sites of Takangshan, Hsiaokangshan, Panpingshan, and Shaoshan, respectively (at Hengchun, the fold is too gentle to allow reliable determination of axis trend). This complex structural pattern (Figure $4 \mathrm{a}$ ) provides a key for interpreting the local deviation of the regional compression in terms of strain and stress "partitioning": the regional $105^{\circ}$ compression has probably been reoriented into a NW-SE compressional stress component nearly perpendicular to the fold axes (and nearly parallel to the NW trending wrench fault zone), "balanced" by an ENE-WSW compression (Figure 9a). These compressions probably followed each other (or alternated) quickly during the Pleistocene.

Taking samples 6 and 7 (Panpingshan area) as an example, we identified a NW-SE compression $\left(133^{\circ}\right.$ and $150^{\circ}$ respectively), perpendicular to the $035^{\circ}$-trending fold axis, and a nearly ENE-WSW compression $\left(067^{\circ}\right.$ and $\left.069^{\circ}\right)$. We therefore suspect "partitioning" in time (during Pleistocene) and space (close to the folds of the Kaohsiung area) of the mean $105^{\circ}$ compression, resulting in an apparent contrast between two Pleistocene compressive trends nearly oblique at $25^{\circ}$ to the $105^{\circ}$ compression (Figure 9b). This hypothesis, however, cannot be checked in detail due to the small number of structural subsurface data available.

The NW-SE extension, parallel to the NW-SE compression and perpendicular to fold axes, corresponds to a local extrados effect: during folding, the tensional stress at anticline hinges (where the reefs developed) resulted in the development of twins, but also of tension cracks and normal faults (Lacombe et al., submitted manuscript, 1996).

The relative chronology of the successive stress regimes could only be recognized based on observations of superimposed striations of fault surfaces, crosscutting relationships between faults related to the same stress systems than twins, or evidence of syndepositional faulting. These observations show that the NW-SE extension was synsedimentary and occurred during folding at the top of anticlines where reef developed. It was followed by the ENEWSW and the NW-SE compressions, expressed in the field mainly by strike-slip faults [Lacombe et al., 1993]. No clear evidence of relative chronology between these compressions was found, suggesting a complex evolution (see above).

\section{Comparison With the Recent and Present-Day Stress Field}

At the scale of the Taiwan collision zone, the present-day stress field (Figures 10a and 10b) determined from borehole breakouts [Suppe et al., 1985] and focal mechanisms of earthquakes [Yeh et al., 1991] evolves from north to south, with a predominant NW-SE compression in the north turning into a WNW-ESE compression in the southern half of the island. All available stress and paleostress indicators (twins, faults, focal mechanisms of earthquakes, and borehole breakouts) suggest that the Quaternary and present-day stress fields in southern and central Taiwan correspond to a major nearly $105^{\circ}$ trend of compression.

However, in detail, borehole breakouts (Figure 10a), focal mechanisms of earthquakes (Figure 10b), and Quaternary faulting (Figures 10c and 10d) additionally show a large 


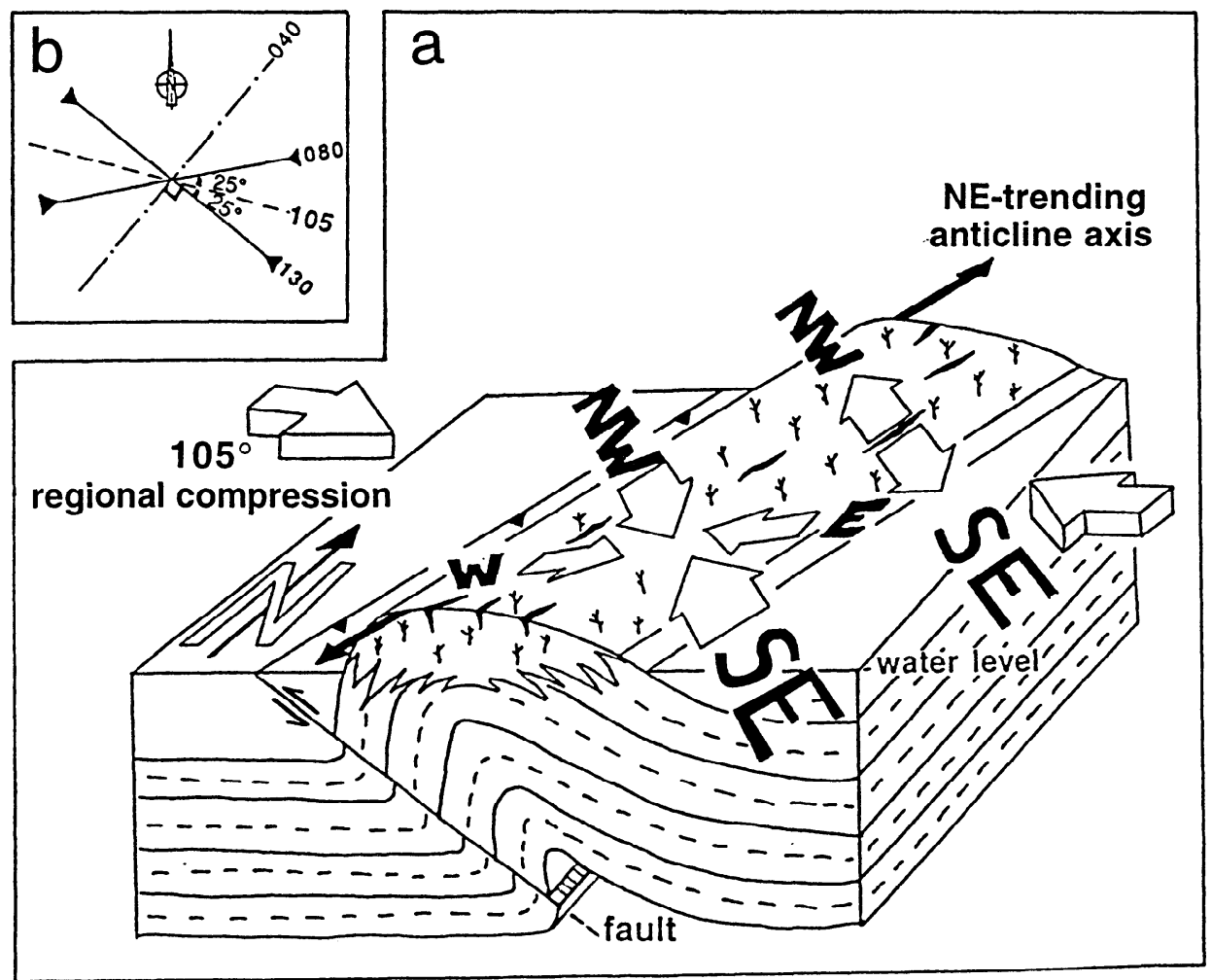

Figure 9. (a) Schematic three-dimensional representation of the states of stress associated with fold anticline development in SW Taiwan. During folding, reef develops on the top of anticline, just below sea level, and emerge progressively during thrusting. The stress field is locally perturbed near the fold, resulting in partitioning in time (see B) of the regional $105^{\circ}$ compressive stress into a NW-SE stress component (nearly perpendiculary to NE-SW folds) and nearly ENE stress component. Extensional fractures form parallel to fold axis, due to extrados stretching at the anticline hinge, in response to local NW-SE extension. B: NW-SE compression $(\approx 130$, perpendicular to 040 fold axis) and ENE-WSW compression $(\approx 080)$, within the framework of the regional $105^{\circ}$ compression.

dispersion of the directions of compression. Relative to the average $105^{\circ}$ trend of compression, this dispersion is large in the investigated area of SW Taiwan, where borehole breakouts indicate both NW-SE and ENE-WSW oriented $\sigma_{\mathrm{hMAX}}$ (Figure 10a) and earthquakes focal mechanisms show ENE $\sigma_{1}$ trends (Figure 10b). These results are in good agreement with the complex distribution of compressional trends deduced from our investigations in Plcistocenc reefal limestones.

The NW-SE extension does not correspond to a present-day stress regime, which suggests that it probably resulted from local effects due to fold development during the Quaternary and not from a deep-seated crustal extension.

\section{Regional Significance and Relations to Plate Kinematics}

In this paper, we demonstate that two Quaternary directions of compression exist near Kenting and Kaohsiung: the nearly ENE-WSW compression and the NW-SE compression. Because the occurrence of polyphase tectonics within a time span of 1.2 Ma is unlikely, we interpret the NW-SE and ENE-WSW compressional trends as the result of a deviation and/or of an heterogeneous distribution of stresses in SW Taiwan during the Pleistocene. These compressive trends are consistent with the present-day nearly $120^{\circ}$ direction of motion of the Philippine Sea plate relative to Eurasia [Seno, 1977; Seno and Maruyama, 1984].

The evolution of the stress field in SW Taiwan, as deduced from (1) fault and twin data analyses, (2) relative chronology between faults, and (3) comparison with the present-day stress field, can thus be summarized as follows (Figure 9a): during the Pleistocene, the regional $105^{\circ}$ trending compression induced formation of $\mathrm{NE}$ trending thrust-related folds on the top of which reefs developed contemporaneously. Stretching at anticlinal hinges created local synsedimentary extensional features related to a NW-SE extension perpendicular to fold axes. During the last stages of folding, the regional $105^{\circ}$ compression underwent partitioning into a NW-SE compression (nearly perpendicular to fold axes) and an ENEWSW compression, which probably followed (or alternated) rapidly during the Pleistocene. This heterogeneous stress distribution is still prevailing in the complex pattern of faulted-folded blocks of SW Taiwan (Figures 10a and 10b). 


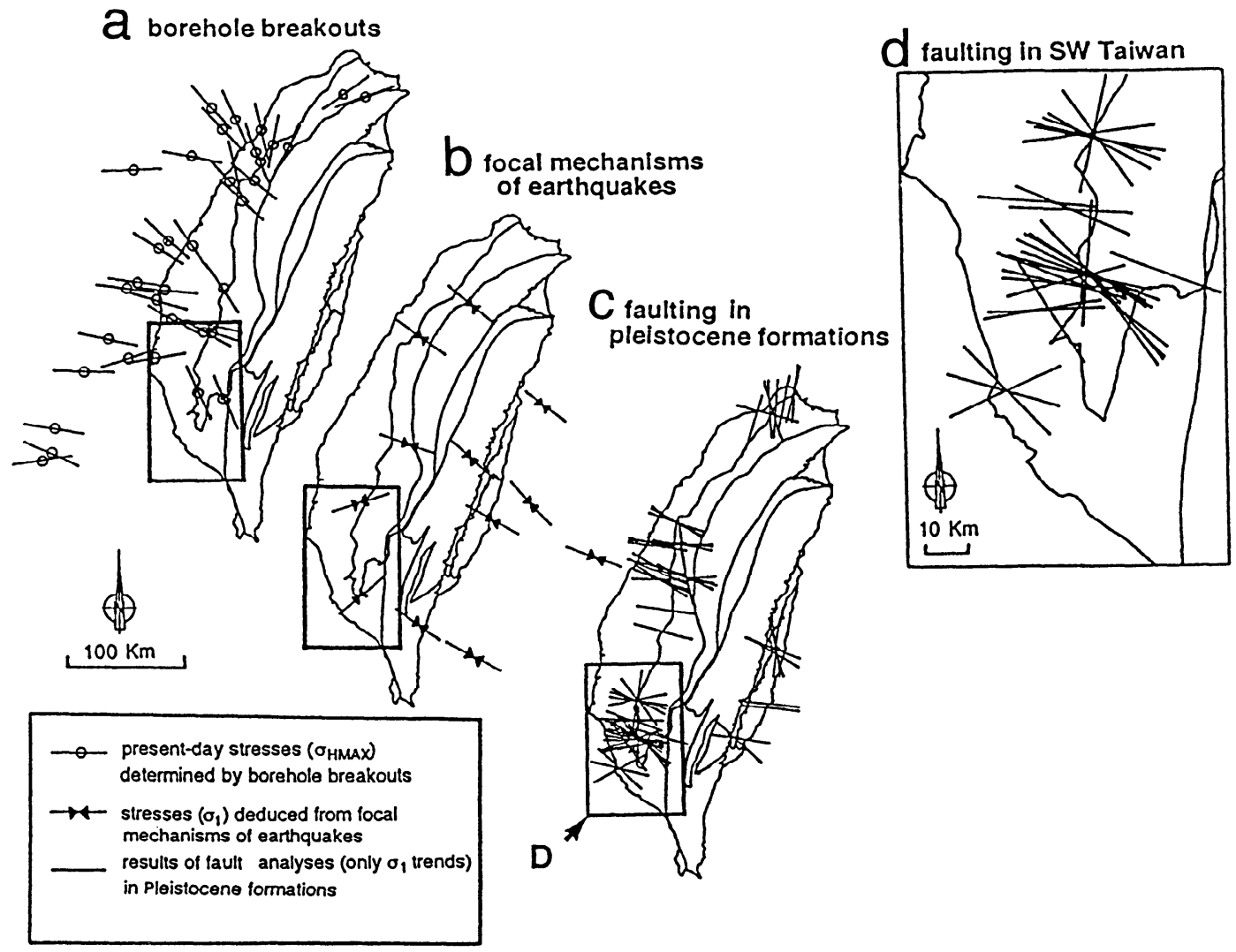

Figure 10. (a) Present-day stresses $\left(\sigma_{\mathrm{hMAX}}\right)$ determined by borehole breakouts [Suppe et al., 1985]. (b) Stresses $\left(\sigma_{1}\right)$ deduced from focal mechanisms of earthquakes [Yeh et al., 1991].(c-d) Results of paleostress analyses in Quaternary formations [Barrier and Angelier, 1986; Angelier et al., 1986; Chu, 1990; Angelier et al., 1990; Lacombe et al., 1993; Lee, 1994]. Figure 10c is whole Taiwan; Figure 10d is Kaohsiung region.

\section{Conclusions}

The inversion of calcite twins from Pleistocene reefal limestones of southwestern Taiwan provides stress systems consistent at the scales of the samples, sites, and regional units. These stress systems reflect the major steps of the Plcistocenc tectonic cvolution of the Taiwan collision. Taking the sources of inhomogeneity into account, the reconstructed stress distributions are closely related to the recent and present-day relative plate motion.

Acknowledgments. Fieldwork and data analyses were supported by the French Institute of Taipei-National Science Council of Taiwan cooperation framework, by the Central Geological Survey of Taiwan, and by the Institut Français du Pétrole. The authors thank P. Cros for his help in the interpretation of coralline structures, as wcll as B. Deffontaines for his help in sampling. Comments by L. Ratschbacher, M. Brooks and D. Delvaux resulted in significant improvement of the paper.

\section{References}

Angelier, J., Tectonic analysis of fault slip data sets, J. Geophys. Res., 89 (B7), 5835-5848, 1984.

Angelier, J., E., Barrier, and H.-T., Chu, Plate collision and paleostress trajectories in a fold-thrust belt: The Foothills of Taiwan, Tectonophysics, 125, 161-178, 1986

Angelier, J., F., Bergerat, H.-T., Chu, and T -Q., Lee, Tectonic analysis and the evolution of a curved collision belt: The Hsüehshan Range, northern Taiwan, Tectonophysics, 183, 77-96, 1990.
Barrier, E., and J., Angelier, Active collision in eastern Taiwan: The Coastal Range; Tectonophysics, 125, 39-72, 1986.

Bowin, C., R.S., Lu, C.-S., Lee, and H., Schouten, Plate convergence and accretion in the Taiwan-Luzon region; A.A.P.G. Bull., 62, 1645-1672, 1978

Burkhard, M., Calcite twins, their geometry, appearance and significance as stress-strain markers and indicators of tectonic regime: A review, J. Struct. Geol., 15 (3-5), 351$308,1993$.
Chen, H.-W., L.-C., Wu, and H.-H., Tsien, The contact relationship between the Early Pleistocene Panpingshan Limestone and Gutingkeng Formation in the Kaohsiung area, southern Taiwan (in chinese), Spec. Publ. Centr. Geol. Surv., 8, 101-119, 1994.

Chi, W.-R., A biostratigraphic study of the late Neogene sediments in the Kaohsiung area based on calcarcous nannofossils: Proceedings, Chung-Kuo Ti Chih Hsueh Hui Hui K'an, 22, 121-144, 1979.

Chi, W.-R., J., Namson, and J., Suppe, 
Stratigraphic record of plate interactions in the Coastal Range of eastern Taiwan; Chung-Kuo Ti Chih Hsueh Hui Chuan K'an, 4, 155-194, 1981.

Chu, H.-T., Néotectonique cassante et collision plio-quaternaire à Taiwan; $P h$. D. Thesis, Mém. Sci. Terre, 90-28, 292 pp, Univ. P. et M. Curie, Paris, 1990.

Deffontaines, B., J.-C., Lee, J., Angelier, J., Carvalho, and J.-P., Rudant, New geomorphic data on the active Taiwan orogen: a multisource approach, $J$. Geophys. Res., 99 (B10), 20,243-20,266, 1994.

Dictrich D. and H., Song, Calcite fabrics in a natural shear environment, the Helvetic nappes of western Switzerland, J. Struct. Geol., 6, 19-32, 1984.

Etchecopar, A., Etude des états de contraintes en tectonique cassante et simulation de déformations plastiques (approche mathématique), Ph. D. Thesis, 270 pp, Univ. Sc. et Tech. du Languedoc, Montpellier, France, 1984.

Friedman, M., Petrofabric techniques for the determination of principal stress directions in rocks, in "States of Stress in the Earth's Crust", edited by W.R. Judd, pp 450-552, Am. Publ., New- York, 1964.

Friedman, M., and H.C., Heard, Principal stress ratios in cretaceous limestones from Texas Gulf coast, A.A.P.G. Bull., 58, 71-78, 1974.

Friedman, M., L.W., Teufel, and J.D., Morse, Strain and stress analysis from calcite twin lamellae in experimental buckles and faulted drape-folds, Philos. Trans. R. Soc. London, A 283, 87-107, 1976

Gong, S.-Y., T.-Y, Lee., J.-C., Wu, S.-W., Wang, and K.-M., Yang, Possible links between Plio-Pleistocene reef development and thrust migration in the southwestern Taiwan; paper presented at the "Active Collision of Taiwan" Symposium, Geol. Soc China, Taipei, Taiwan, March 22-23, 1995.

Groshong, R.H., Experimental test of leastsquares strain gage calculation using twinned calcite, Geol. Soc. Am. Bull., 85, 1855 1864, 1974.

Groshong, R.H., O.A., Pfiffner, and L.K., Pringle, Strain partitioning in the Helvetic thrust belt of Eastern Switzerland from the leading edge of the internal zone, J. Struct. Geol., 4, 429-442, 1984.

Handin, J.W., and D., Griggs, Deformation of Yule marble, II, Predicted fabric changes, Geol. Soc. Am. Bull., 62, 863-886, 1951.

Ho, C.-S., A synthesis of the geologic evolution of Taiwan, Tectonophysics, 125, 1-16, 1986.

Jamison, W.R., and J., Spang, Use of calcite twin lamellae to infer differential stresses, Geol. Soc. Am. Bull., 87, 868-872, 1976.

Lacombe, O., Maclage, fracturation et palécontraintes intraplaques: Application à la plate-forme carbonatée ouesteuropéenne, Ph. D. Thesis, Mém. Sci. Terre,
92-24, 316 pp, Univ. P. et M. Curie, Paris, France, 1992

Lacombe, O., J., Angelier, P., Laurent, F., Bergerat, and C., Tourneret, Joint analyses of calcite twins and fault slips as a key for deciphering polyphase tectonics: Burgundy as a case study, Tectonophysics, 182, 279 $300,1990$.

Lacombe, O., J., Angelier, and P., Laurent, Determining paleostress orientations from faults and calcite twins: A case study near the Sainte-Victoire Range (southern France), Tectonophysics, 201, 141-156, 1992.

Lacombe, O., J., Angelier, and P., Laurent, Les macles de la calcite, marqueurs des compressions récentes dans un orogène actif: L'exemple des calcaires récifaux du sud de Taiwan, C. R. Acad. Sc., Ser. II, 316 , 1805-1813, 1993.

Laurent, P., Les macles de la calcite en tectonique: nouvelles méthodes dynamiques et premières applications; $P h$. D. Thesis, 324 pp, Univ. Sc. et Tech. du Languedoc, Montpellier, France, 1984

Laurent, P., P., Bernard, G., Vasseur, and A., Etchecopar, Stress tensor determination from the study of $e$ twins in calcite: A linear programming method, Tectonophysics, 78 , 651-660, 1981.

Laurent, P.,C., Tourneret, and O., Laborde, Determining deviatoric stress tensors from calcite twins. Application to monophased synthetic and natural polycrystals, Tectonics, 9, 379-389, 1990.

Lee, J.-C., Structure et déformation active d'un orogène: Taiwan; Ph. D. Thesis, Mém. Sci. Terre, 94-17, 324 pp, Univ. P. et M. Curie, Paris, France, 1994.

Nissen, H.U., Dynamic and kinematic of crinoids stems in a quartz grauwacke, $J$. Geol., 72, 346-360, 1964.

Pfiffner, O.A., and M., Burkhard Determination of paleo-stress axes orientations from fault, twin and earthquake data, Ann. Tectonicae, 1, 48-57, 1987.

Rocher, M., La déformation microscopique des calcaires récifaux quaternaires de Taiwan: De l'analyse des macles de la calcite à la quantification des contraintes au front d'une chaine de collision, DEA Mem., S.G.F., cote $36647,62 \mathrm{pp}$, Univ. P. et M. Curie, Paris, France, 1994

Rocher, M., Résultats de l'analyse microtectonique dans un front de chaîne actif: Le Sud-Ouest de Taïwan, Mécanique des Milieux Discontinus et Reconstitution des Contraintes, Int. rep. Inst.. Franç. Petr., des Milieux Discontinus et Reconstitution des Contraintes, Int. rep. Inst.. Franç. Petr., 48 pp., Rueil Malmaison, France, 1996.

Rowe, K. J., and E.H., Rutter, Paleostress estimation using calcite twinning: Experimental calibration and application to nature, J. Struct. Geol.,12, 1-17, 1990.
Seno, T., The instantaneous rotation vector of the Philippine Sea plate relative to the Eurasian plate, Tectonophysics, 42, 209226, 1977.

Seno, T., and S., Maruyama, Paleogeographic reconstruction and origin of the Philippine Sea, Tectonophysics, 102, 53-84, 1984.

Spiers, C.J., Fabric development in calcite polycrystals deformed at $400^{\circ} \mathrm{C}$; Bull. Mineral., 102, 282-289, 1979.

Sun, S.-C., The reef limestones and the geologic structures in the vincinity of Kaohsiung City, Taiwan, Spec. Vol. Petr. Geol. Taiwan H.H.Ling's Birthday, 2, 47-64, 1963.

Suppe, J., Mechanics of mountain-building and metamorphism in Taiwan; Chung-Kuo $T i$ Chih Hsueh Hui Chuan K'an, 4, 67-90, 1981.

Suppe, J., C.-T., Hu, and Y.-J., Chen, Presentday stress directions in western Taiwan inferred from borehole elongation, Petr. Geol. Taiwan, 21, 1-12, 1985.

Teng, L.-S., Stratigraphic records of the late Cenozoic Penglai orogeny of Taiwan; Acta Geol. Taiwan, 25, 205-224, 1987.

Teng, L.-S., Geotectonic evolution of lateCenozoic arc-continent collision in Taiwan, Tectonophysics, 183, 57-76, 1990.

Tourneret, C., and P., Laurent, Paleostress orientations from calcite twins in the north pyrenean foreland, determined by the Etchecopar inverse method, Tectonophysics, 180, 287-302, 1990.

Tsai, Y.-B., Seismotectonics of Taiwan; Tectonophysics, 125, 17-37, 1986.

Tullis, T.E., The use of mechanical twinning in minerals as a measure of shear stress magnitudes, J. Geophys. Res., 85, 62636268, 1980.

Turner, F. J., Nature and dynamic interpretation of deformation lamellae in calcite of three marbles, Am. J. Sc., 251 , 276-298, 1953.

Turner, F.J., D.T., Griggs, and Heard, H., Experimental deformation of calcite crystals, Geol. Soc. Am. Bull., 65, 883-934, 1954.

Yeh, Y.-H., E., Barrier, C.II., Lin, and J., Angelier, Stress tensor analysis in the Taiwan area from focal mechanisms and earthquakes, Tectonophysics, 200, 267-280, 1991.

J. Angelier (e-mail: ja@lgs.jussieu.fr), $O$. Lacombe (e-mail: lacombe@lgs.jussieu.fr), and $M$. Rocher, Laboratoire de Tectonique Quantitative, Université P. et M. Curie, Tour 26-25, E1, Boîte 129,4 place Jussieu, 75252 Paris Cedex 05, France.

H.-W. Chen, Central Geological Survey, P.O. Box 968, Taipei,Taiwan.

(Received February 17, 1995; revised January 22, 1996; accepted January 22, 1996.) 